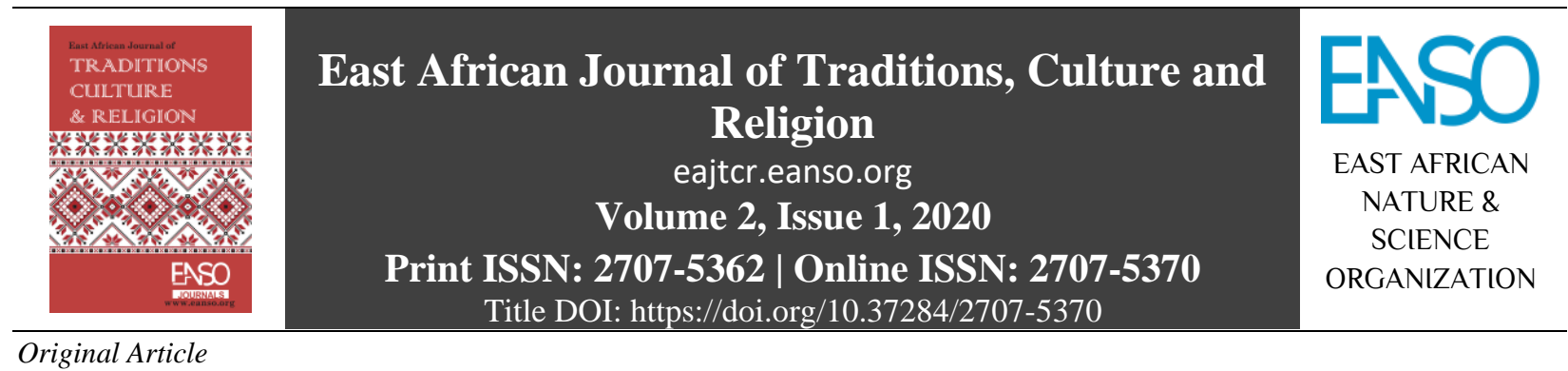

\title{
The Fate of Prosperity Gospel in Kenya
}

\author{
Bernard Alwala ${ }^{*}$ \\ ${ }^{1}$ Department Economics and Humanities, School of Arts and Social Sciences, Rongo University, Main Campus, Kenya. \\ ${ }^{*}$ Correspondence Email: alwalaben@ rocketmail.com
}

Article DOI: https://doi.org/10.37284/eajtcr.2.1.141

\section{Date Published: ABSTRACT}

14 May 2020 The prosperity gospel announcement is new in religious scenery but is speedily growing at a force to be taken into consideration in Kenya. It has a greater

Keywords: chance of enduring beyond our contemporary society to the coming century. This is because its elements are commonly and easily acknowledged by people

Gospel, from all walks of life. This common acceptance can be attributed to its two main

Fate, prerogatives, that is, corporeal and psychic authorisation to human nature. This

Kenya, study adopted a phenomenological method. The study revealed that there are so Prosperity, many in support of the enlargement and alliance of the gospel of prosperity in Neo-Pentecostalism. Kenya to the extent that it is no longer a Pentecostalism gospel, but also the mainstream churches have adopted it to some degree. The paper reviewed the origin and adoption of the prosperity gospel in Kenya; features of neoPentecostal prosperity gospel and factors that sustain it as well as the future of prosperity gospel in Kenya. This paper concluded that the fate of prosperity gospel could be speculated under three ideologies. That is; virtually complete decline; fluctuating endurance; and morphological evolution. Essentially, the prosperity gospel is not bad in its entirety, but what is required is a transformation of the bad elements into the right emphasis. The paper speculates that the prosperity gospel may undergo some morphological evolution to make it more suitable to the contemporary needs for it to continue being relevant in Kenya.

\section{APA CITATION}

Alwal, B. (2020). The Fate of Prosperity Gospel in Kenya. East African Journal of Traditions, Culture and Religion, 2(1), 1-9. https://doi.org/10.37284/eajtcr.2.1.141

\section{CHICAGO CITATION}

Alwala, Bernard. 2020. "The Fate of Prosperity Gospel in Kenya". East African Journal of Traditions, Culture and Religion 2 (1), 1-9. https://doi.org/10.37284/eajtcr.2.1.141.

\section{HARVARD CITATION}

Alwala, B. (2020) "The Fate of Prosperity Gospel in Kenya", East African Journal of Traditions, Culture and Religion, 2(1), pp. 1-9. doi: 10.37284/eajtcr.2.1.141. 
East African Journal of Traditions, Culture and Religion, Volume 2, Issue 1, 2020

Article DOI: https://doi.org/10.37284/eajtcr.2.1.141

IEEE CITATION

B. Alwala, "The Fate of Prosperity Gospel in Kenya", EAJTCR, vol. 2, no. 1, pp. 1-9, May. 2020.

\section{MLA CITATION}

Alwala, Bernard. "The Fate of Prosperity Gospel in Kenya". East African Journal of Traditions, Culture and Religion, Vol. 2, no. 1, May. 2020, pp. 1-9, doi:10.37284/eajtcr.2.1.141.

\section{INTRODUCTION}

The worldwide magnitude of the progress of prosperity gospel has not only been very dramatic but also inspiring over the past years. According to Sinitiere, Pentecostalism is such a lively and unsolidified group of worship that has a wide and diverse gathering (2013). Ojo (2013), traces its origin as a brand of Pentecostalism, which has its source in America. He continues to state that, prosperity gospel was a small branch of Pentecostalism, but to date, it is universally recognized. The prosperity gospel is a very distinct character of Charismatic Pentecostalism in Kenya. In our current society, Pentecostalism has become attractive because it presents a consoling explanation for why good people continue to experience good things while bad people experience downturns. It also provides economic stewardship in Christian churches by being independent of western funding. Since religion indoctrinates to the extent of interfering with reasoning, the doctrine of prosperity is impacting heavily in Kenya and to convince the members otherwise is a difficult task.

The interest that prosperity preaching generates consequent growth, popular influence, and triumphs over the preaching of integral development by the mainstream churches especially Catholic theology of preferential option for the poor and integral development by other mainstream churches triggered the desire to conduct this review. The prosperity preaching has made the mainstream churches suffer a loss of congregants who are swayed by the prosperity gospel, but later they come back due to 'unrecovered syndrome.'

The scope of this review is limited to determining the feasible fate of the prosperity gospel in Kenya. This is done through an attempt to project into the future of prosperity gospel. It is inescapable in this paper to clarify that we are not sure of the future apart from God who omniscience. The knowledge of the future is upon God Himself and we are to be certain of it because we cannot use the finite mind to understand the infinite. In other words, this paper cannot claim an accuracy of prediction to the fate of the prosperity gospel in Kenya.

\section{THE ADOPTION OF PROSPERITY GOSPEL IN KENYA}

The origin of the faith formula movement or "gospel of prosperity" has been well described by Paul Gifford, with reference to Liberia. According to Njeru (2001), the beginning of the prosperity gospel is ascribed to Kenneth Hagin of Tusla, Oklahoma who claimed to have received a revelation in 1934 regarding the text of Mathew 11:23.

Hagin taught that prayer for well-being and material wealth is perfectly responded to when one sincerely believed that the things prayed for would be granted. After serving as a Baptist preacher and then as a pastor, he founded his own Bible Training Centre in 1974, and his gospel of prosperity and success began to flourish. One of his repeated sayings was that anyone who does not drive a luxury car had not understood the gospel.

In 1979, Hagin's son, Kenneth Junior aided to establish the International Convention of Faith Churches and Ministers. Through this body, the faith gospel became even more extensively known. Hagin's successor Kenneth Copeland took the doctrine around the world in the 1980s through seminars and publications. The prosperity gospel presents two basic tenets, that is, God wants the Christian to be rich and that poverty is an indication of personal sin. The other is based on a provocative reading of 2 Corinthians 9 , which is, in order to reap, one must sow (Njiru, 2001).

The above tenets mean that the Christians must contribute plentifully to the work of evangelization and to the maintenance of pastors if one wishes to 
enjoy good health and material wealth. In the gospel of prosperity churches' tradition, personal testimony sometimes takes more important place than the Bible sharing. In Kenya, the spread of this gospel started with the entry and advocacy of prosperity preaching by Pentecostal churches.

In recent decades, a new breed of the preaching of 'panda mbegu' has emerged in most of the towns in Kenya. This new breed has been referred to by several names. These include Pentecostalism", "neo-Pentecostalism", charismatic renewal and "charismatic Christianity" to differentiate it from the old Pentecostal churches which originated from protestant churches. Most of the proponents of this gospel originate in the $21^{\text {st }}$ century. One feature that this Neo-Pentecostalism distinct from the classical Pentecostalism is that, they are majorly found in urban areas while classical Pentecostalism is found in both urban and rural areas. In fact, according to Togarasei (2005), Neo-Pentecostalism is a town issue that has largely drawn its following from middle-class members in the urban areas, the educated, and the fairly educated. It means that the poor in these churches are majorly new converts faced with problems of poverty or health.

According to Ndegwa, the prosperity gospel mainly attracts the youth, especially in universities and colleges. He adds that the Neo-Pentecostalism gets most of its worshipers from slums of major towns in Kenya such as Kibera and Mathare in Nairobi, Manyatta and Kondele in Kisumu and Kaptembwa in Nakuru among others. Ndegwa reports that the Registrar General's office has a lot of clerical work due to the increasing demands for registration of new churches (Ndegwa, 2007). He continues to report that, The Attorney General Amos Wako, speaking in a workshop for church leaders reported that the sector is extremely busy due to the demand for registration of new revival churches with awaiting submissions of about 6,740. The Attorney General by then exposed that there are about 8,520 registered churches and about 60 submissions are filed every month. Most of these churches have only sprouted and concentrated in major towns some are even closely adjacent to each other. Some are huge while others are not worth being called churches according to their size of membership. These churches also add to the number of pending applications in the Office of the Registrar for Churches and related organizations.

According to Shorter \& Njiru, Kenya has progressed with robust Pentecostal and charismatic custom. This is shown by the frequent open-air rallies, big crusades in stadiums, restoration gatherings, prayers for miracles, conventions, healing ministries, and itinerant preachers in buses, among others. Some of these churches have even developed the use of Television. Televangelism is a significant feature of the Kenyan prosperity gospel preaching (Shorter \& Njiru, 2001). Writing about Nigeria, Marshall (1998) corroborates with the above authors. He states that many new churches and evangelical groups have sprouted up in cities and towns forming religious groups with a moving and religious power and force. The above statement is true universally.

Since the 1980s, but more expressively in the 1990s until today, Pentecostal and Charismatic movements, fellowships and ministries have increased all over the country. These churches include, the Christ is the Answer Ministry (CITAM), The Mavuno Church, and the Winners Chapel International Ministries among others. We cannot claim to exhaust the list because as soon as you give a list, another church sprouts. The truth of the matter is that, the majority of the Kenyan population associates with Pentecostal and charismatic movements.

The Pew Research Centre (2003) survey report that the Pentecostal/Charismatic movements is followed by most of the Kenyan population, in fact, to be specific, it reports that more than half of Kenya's population. The survey on religious demography and health survey found that out of the $88.5 \%$ of the population who are Christians, 62.6 per cent are protestants and the majority of the protestants are Charismatics. This report indicates that charismatic Pentecostalists who are the proponents of prosperity gospel commands the majority of the Kenyan population.

The growth of neo-Pentecostal Christianity in Kenya is both numerical, ecclesiastical, and social. This growth can be associated with rural-urban migration in search of greener pastures, education, and aggressive evangelism way of preaching in both English and Kiswahili. This attracts the youth 
and people of 'class", mainly the haves and the collapse of the Kenyan economy where the majority are job seekers. Asamoa-Gyadu adds that this progress has also been powered by church establishing, lay deployment, active music, and the festive and ritual nature of praying (2007). Many of them have grown enormously not only in membership but also in their institutional structures. Their impact has also conquered all facets of Kenya as a country. It penetrates both civic and economic life. Their influence in economic development is as a result of their hiring of some facilities like halls to be used as churches, choir and music bands and billboards in towns for advertisement. Politically, they also give a soft platform for most politicians, especially during general elections. Lastly, their enormous influence is recognized not only in adding to the number of Christians but also psychotherapeutic and counselling services to the members of the society.

\section{UNIQUE FEATURES OF NEO- PENTECOSTALISM}

The most distinctive and easily recognizable elements of neo-Pentecostalism movements in Kenya which makes it attractive to the multitudes of people can be attributed to its great concern with economic deficiency among the people who are the majority in Kenya. Pentecostalism helps people to endure both socially and mentally since it provides communal support, emotional release and a sense of individuality and dignity for a vast range of social groups. There are many features of prosperity Neo-pentecostalism. Some of these factors are behind its attraction to the masses. Among the factors mentioned by researchers as distinguishing features of prosperity Neo-pentecostalism, Asamoa-Gyadu isolated four most significant ones.

First, is its attraction to the young people. These churches are largely occupied by young people. They have the youth in their leadership structures while some are the founders. Some of these churches began as Christian Unions in higher institutions of learning like colleges and universities. Their founders were worship leaders in these institutions. Due to their advocacy of prosperity gospel, they appeal to most of the youth.
Secondly, is its openness to modernism. Most of these churches have incorporated innovation and are methodically contemporary in their outlook and way of worship. These churches presence to appear successful and portray an international image in terms of language, the order of worship and use of technology.

Thirdly, New Pentecostal churches have a special attraction to the African youth. This is because they have lay-oriented leadership where even women take up key positions like being pastors, ecclesiastical office based on a person's charismatic gift, advanced use technologies, and a relaxed fashion code for members. Most of the key leaders of these churches are moderately young people who have exercised some gifts like preaching, leading worship songs and leading Bible sharing in the prayer groups.

Lastly, is the use of English as the language to spread their gospel to the people. Though, English remains the most favoured language, preaching and personal testimonies are also translated in Kiswahili. In a case where they are found in the village set up, they often use the three languages that are English, Kiswahili and a local language. Songs in the English language are heavily used in their interpreted Kiswahili form and some vernacular languages when used in the village set up. The above translations of songs positively enculturate the culture of the people hence makes the songs more appealing to the congregation.

Other researchers like Wolf (2006), presents its attractive feature as the close link between prosperity Pentecostalism and poverty because of it consoles the poor. It provides most urban dwellers who are poor with powerful psychic and emotional experiences that assist as a foundation of comfort in people's lives that are disheartening and disregarded.

Adeboye (2006) states that another feature that makes it attractive is the lack of state to be more aggressive in matters concerned with the management of modernization. They not only prescribe to the spiritual needs of the people but also analyse and recommend spiritual therapies for issues considered by the majority to be outside the religious sphere. Neo-pentecostalism serves both spiritual and political spheres of life. Their pastors 
and bishops can serve as preachers and members of the parliament to represent a constituency.

Other features commonly observed in Kenyan towns include the use of empty spaces for worship. These spaces include cinema halls, public parks, school fields, bus parks, and unfinished or abandoned buildings. In Kisumu, for example, they use Taifa park every lunchtime, mainstage, and they are also found in moving public vehicles, especially buses. In fact, these churches seem to be competing with the business community.

The last distinctive feature which makes this gospel attractive is its use of new technologies in communication in the broadcasting of its message. Some of these technologies include propagation through Television, PowerPoint presentations, radio, Facebook and Twitter, mobile phones, among others. They send bible messages and billboards where they can write a theme of reflection. For example, the Deliverance Church uses televangelism, computer technology to reach a wide audience through email. Most of these churches also have launched websites to reach the whole world. These websites include the Bible Society of Kenya at www.forministry.com, among others. Sermons and other religious mails and programs of the week are posted on these websites.

Neo-Pentecostal/Charismatic movements have succeeded in making an indelible character in religious organizations in the world. These characters are unique from what other churches are offering. This could be the reason why they easily attract the majority of Kenyans. What then is the factors that sustain this gospel in Kenya. This is the question we must try to investigate.

\section{FACTORS THAT SUSTAIN PROSPERITY GOSPEL IN KENYA}

The factors that sustain prosperity gospel denominations in Kenya become their strengths. These churches enthusiastically promote economic stewardship. Through their faithful giving of tithe and generous contributions of the church members, evangelism activities can be funded, church structure constructed, salaries for pastors paid and modern electronic mass media equipment purchased. They epitomize the struggle depicted by local African churches that are intended to become self-supporting. The prosperity gospel churches also offer their members a motivation for a socioeconomic rebuilding. They allow their members to "recast their poverty" as something personal and temporary, an individual accepts that he/she can do something about it. This generates both hope and effort to overcome poverty.

Several scholars have argued that prosperity gospel provides comfort, consolation, and support more than it provides a basis for social-oriented action to change structural conditions in society as it clams. The prosperity gospel Neo-Pentecostalism is surely vitalized in Kenya and is progressively presenting itself to be felt in the whole country. The prosperity preaching is advancing even into the classical churches despite its several and persistent attacks by the mainstream churches. The factors that enable prosperity gospel in Kenya to continue thriving is now the area of investigation. These strengths of prosperity gospel will enable it to flower amidst criticism. If these strengths come to an end, it will automatically mark the end of the prosperity gospel in Kenya. Among the host of factors mentioned by researchers as strengths of the prosperity gospel, Kitause and Achunike (2015) isolate eight of the most significant ones:

First, is the irresistible admiration of prosperity gospel; the prosperity gospel being a popular theology of modern living, based on, faith, health, wealth, and victory; its basic formula that spiritual power is released through victory on earth is admired by several people. In the $21^{\text {st }}$ century, there seems to be a growing number of people that are turning willingly towards healing religion that appeases the soul than religions that are foreign to the needs of the people. This makes most Christians to be swayed from the classical churches though some go back again to their earlier denominational affiliations. The prosperity gospel has the tone, vocabulary, approach, and irresistible convincing power to do such.

Secondly, is the astronomical expansion of prosperity ideology. According to Phiri and Maxwell (2015), prosperity ideology is growing faster than any Christian ideology and other religions like Islam. Their ideology is more relevant to the economic situation of most Kenyans and 
effectively substitutes the traditional religion in matters concerning curse, witchcraft and active way of worship characterised by dancing and music. Their tenets essentially percolate than other classical churches and religious doctrines.

Thirdly, is deeply rooted poverty level in the African continent. The number of people living below the poverty level that is 1.90 dollar per day in Africa is at a high increase level. According to poverty clock report, Kenya is ranked $8^{\text {th }}$ globally and sixth in Africa among the countries with the highest number of persons living in thrilling poverty,(Business Daily, 2018). The report says that $29 \%$ (14.7 million) of the $49,684,304$ people are very poor as they consume less than $\$ 1.90$ per day. This adverse poverty level in Kenya will surely provide a soft landing for prosperity gospel preaching in Kenya. This work deduces that as long as poverty continues to thrive in Kenya and other parts of Africa, the prosperity gospel is neither going to lessen its flavour nor its appealing ideology to the poor in Kenya and Africa as a whole.

Fourthly is the innate human desire and search for a better life. The desire to rise above the poverty level by most of the people in Kenya, especially the youth makes them be lured by prosperity gospel churches with the hope of solutions to their unpleasant status quo. Generally, people think of urban areas as places of greener pasture and it is in urban areas where this prosperity preaching concentrates. This follows that they will have to encounter these proponents of the prosperity gospel and surely, they will be easily swayed by their teachings.

The fifth is a simple easy-going 'theology of Sweat less Prosperity'. The theology of prosperity gospel is that God desires all believers who have sufficient faith to prosper in life. According to Lin (2015), it is reported that $83 \%$ in Kenya, with 96 per cent in Nigeria, and 80 per cent in South Africa believes that, God grants material wealth to all those who have strong faith in Him. The above data clearly shows that many prescribe to the belief system that God can in a way provide for then like He provided mana to the Israelites, can bring wealth to those who have faith.

The sixth point is the evangelistic campaign and churches proliferation. Pentecostal churches experience growth at high speed. This growth is both in numerical and structural. For example, according to Droz (2001), Mavuno Church, Nairobi Chapel, Christ is the answer ministry ( CITAM) which has been growing steadily. He reports that, between 1972 and 1986, the number of Pentecostal churches in Nairobi alone doubles. He continues as presented by Pew Forum that, televangelism, prosperity theology and crusades by western preachers become more prevalent in Kenya. For example, in early 2006, T. D. Jakes from America attracted approximately million people to Uhuru Park in Nairobi. The Forum's 2006 Pentecostal survey also reports that renewalists including charismatics and Pentecostals account for more than half of Kenya's total population as at that time population.

The survey also founded that nearly seven out of ten protestants in Kenya are Pentecostals or Charismatics. The report continues to state that about one-third of Kenyan Catholics can be classified as charismatics. This is because of some prosperity gospel elements that can be found in them (Pew report, 2010). Some other charismatic churches like Jesus is Alive Ministry (JIAM), Faith Evangelist Ministry (FEM) and Parkland Baptist Church not only commands a large congregation but also are speedily growing with towns and cities. Neno Evangelism Centre, The Assemblies of God and the Winners Chapel are making serious developments everywhere. Based on the projection and strategies of some of these churches to evangelize to the world, it is expected that many Christians will shortly join Pentecostal in the coming centuries. This can lead to more than 70 per cent of the global Christian population, becoming prosperity gospel church affiliates. The challenge caused by these prosperity gospel churches in Kenya is a force to reckon with. For this, it is not a surprise that prosperity gospel is slowly entering 
into even the mainstream churches like Catholics, Anglicans, and Seventh-Day Adventist churches. This is evident in their songs and preaching by their priests and bishops. A case of the song in Catholic church mostly the sadaka songs. For example, one song in a stanza states, toa tu ulicho nacho ndio unabarikiwa...,Mungu anakuona mpaka moyoni mwako (literally translated as, just contribute what you have to receive blessings, God sees you inwardly up to your soul.

The seventh factor is the nature of Pentecostalism. The phenomenological appearance of pentecostalism is more attractive to Africans than the sober celebrations in the mainstream churches like Catholics and Seventh Day Adventist Church, among others. African seems to have an irresistible urge towards the very active celebrations characterized by music, dance and clapping. These prosperity Pentecostal churches even allow modern and secular dances in their ecstatic celebrations. The dances and music essentially attract the youth, unlike the celebrations in other churches which are sober and the youth consider them boring. The celebration here is almost a better alternative to their traditional festivals and ceremonies. The NeoPentecostal/ charismatic prosperity gospel churches offer if not exact but close to what the contemporary youth may want in the church.

The eighth point is that prosperity Gospel has protection against magic and problems. The NeoPentecostal prosperity gospel churches attractively address issues of witchcraft. Prosperity gospel promises people protection in their life after their prompt contributions through seed faith. For this reason, members feel protected against two major threats of human life, that is poverty, diseases which most Africans believe that could be caused by witchcraft. The churches seemingly expand numerically but not qualitatively in terms of faith. In times of crisis, most of her members either go back to his/her original church or have a blend of the two denominations. This could be one of the reasons why there is syncretism in Africa or what I may refer to as unrecovered Christian syndrome. They become church hoppers and remain neophytes.

The numerical growth is a matter to rejoice over, but it makes Christians not to be deeply rooted in
Christ. The post consequence is that these Christians remain neophytes and rarely can they practice personal belief in God away from the church gatherings, (Harries, 2000). It is a common reality that it is human nature to seek protection. This nature of man is also what we believe to be the origin of all world religions. For this reason, nature to seek protection cuts across all humanity. When any substitute for protection arises, people incline to the source. Africans who believe in magical powers tend to patronize prosperity gospel for protection against, sorcery, evil eye, witchcraft, and curses. This idea is propagated by prosperity preachers. It is until recently that they have not given a valid reason for the COVID-19. Most of them through online preaching attribute to punishment from God while others are silent about it. These preachers stress this Biblical verse "when I shut up the heavens so that there is no rain, or command the locust to devour the land or send pestilence among my people" (2 Chr. 7: 13).

Lastly, the gospel of prosperity is sociologically relevant. The prosperity gospel is not only about money, health, and witchcraft, but also it contributes to the political platforms in Kenya. Most politicians flock the churches during campaigns; hence they become a readily available audience for political rallies without being organized by the politicians themselves. In social life, they offer a soothing and consoling service to many people faced by problems and lastly, economically, they boost the Kenyan economy in Hotel industry, land rates and parking fees especially in towns where they concentrate. They offer a source of the market to manufacturers, especially the electronics, phones, laptops, hired choirs. A good number of people get their livelihood from these churches. Sinitiere (2013) further adds that it enculturates itself to the locals, and apparently, it is rising among the poor people and the side-lined. It provides communal support in situation of social breakdown and living as a true "church of the poor" seeking both spiritual and physical empowerment to free themselves through God's power from oppression. 


\section{THE FATE OF PROSPERITY GOSPEL IN KENYA}

Considering the lively future which prosperity Pentecostalism seems to have, this paper now tries to speculate about what future holds for prosperity gospel over the next several centuries in Kenya (e.g., to the year 2400), and identifies three categories of predictions: virtually complete decline; fluctuating endurance; and morphological evolution. It then considers high-level arguments for and against them.

Considering virtually complete decline, it appears that there will reach a time and a season when those who seek prosperity gospel will get disappointed with their principle of sowing and reaping. It is logical that if people sow seeds of faith in prosperity ministry churches but fail to get a positive expected outcome, it is human nature that they will automatically get discouraged and fall back to classical churches. Their same irresistible urge to plant a seed of faith for prosperity will again be used to fall back. It will be likened to St. Paul, the strength he used to persecute Christians is the same strength he used to preach Christianity after the Damascus event. The prosperity gospel later may also become a common phenomenon to Kenya's population and becomes no longer attractive. It is a reality that people tend to be attracted to a new phenomenon. This will be the end of the prosperity gospel and religion. This is a prediction that foresees the end of faith soon.

It is a prediction based on an extrapolation of currently widespread secularism in some large regions of the world, such as Western Europe or China, or on the recent rise of "Nones" in the United States. In this spirit, a predictor of the end of prosperity gospel and religion could argue that other social systems will evolve that they will provide virtually all the benefits of prosperity gospel discussed in our paper as factors sustaining prosperity gospel.

In terms of fluctuating endurance, prosperity gospel in Kenya may be here to stay as long the unpleasant status quo of the poverty level, challenges of diseases and factors that sustain it continue to endure. At this level, the details of what prosperity stresses may evolve to adapt to the various situations in Kenya, but essentially it remains the prosperity gospel.

Lastly, in terms of morphological evolution; we can argue that over a very long period, occasional major changes, or paradigm shift, in social systems will be observed. This reality is true of the governmental structures that supply legal systems and the education system in Kenya as an example. Consider governmental evolutions from chiefdoms to empire, a central system to a combination of a county system with the central system. Even in the education sector from 7-4-2-3 in 1963 to 8-4-4 system in 1981 and now a major departure from 84-4 to proposed CBC launched in 2017 which comprise of 2-6-3-3. Such phenomena raise the possibility that major evolutionary changes can also in prosperity gospel preaching. There may well be paradigm shifts in how prosperity is structured, presented, and implemented, and in what their pragmatic consequences are. And some of the new paradigms may prove to be a success in getting themselves replicated because they will add something in a cost-effective way to what will be supplied to humans by other kinds of social systems.

\section{CONCLUSION}

This paper makes speculation into the fate of prosperity gospel in Kenya. It has recognised that the future of prosperity gospel Pentecostalism will remain bright in Kenya owing to several factors that are identified above. The paper deduces that prosperity gospel will continue to flourish in Kenya if the unpleasant status quo of poverty and challenges by diseases remains constant. The prosperity gospel is likely to continue beyond the $21^{\text {st }}$ century.

On the other hand, it is anticipated that all those people who subscribe to prosperity gospel churches to get wealth, will eventually fall back due to unrecovered syndrome nature of human beings. The numerical growth will eventually reduce or even suffer extinction after a long period of time.

Lastly, this paper is of the view that the prosperity gospel will morphologically evolve to a more suitable structured and well-packed way of presentation. That is to say, the prosperity gospel is 
not essentially bad, but the negative elements are to be changed in the right direction of the message of prosperity. This change would be achieved through prosperity evolving morphologically. Though we are incompetent to talk on behalf of God, we believe that God will change it to something positive and preachers will be able to positively contextualize the theology effectively in their contemporary society, to address the societal needs of the time. Essentially prosperity gospel in there to stay in Kenya, it may only change on the periphery, but it remains the same.

\section{REFERENCES}

Adeboye, O. (2006). Pentecostal challenges in Africa and Latin America: a comparative focus on Nigeria and Brazil. Afrika Zamani, 11(12), 2003-2004.

Asamoa-Gyadu, K. (2007). Born of Water \& Spirit: Pentecostal-Charismatic Christianity in Africa. Trenton New Jersey: Africa World Press.

Gifford, P. (2009). African Christianity and the Eclipse of the Afterlife. Studies in Church History, 45, 413-429.

Gifford, P. (2009). Christianity, Politics and Public Life in Kenya. London: Hurst \& Company.

Harries, J. (2000). The magical Worldview in the African Church: What is going on? Missiology, 28(4), 487-502.

Kitause H. Rimamsikwe \& Achunike C. Hillary ( 2015). The future of Prosperity Gospel in Nigeria. Quest Journal; Journal of Research in Humanities \&Social Sciences, vol 3-issues 7(pp. 21-27). Retrieved from www.questjournals.org>vol3-issue 7.

Lin, T. T. (2015). Prosperity Gospel: There is Hope in Africa. Retrieved from http://iascculture.org/THR/channels/THR/tag/prosperity -gospel/.

Marshall, R. (1998). Pentecostalism in Southern Nigeria: An Overview. In Gifford, P., African Christianity: its public role (pp. 7-32). London: Hurst and Company.
McCain, D. (2000). The Church in Africa in the twenty-first century: characteristics, challenges, and opportunities. Africa Journal of Evangelical Theology, 19(2), 105-130.

Ndegwa, A. (2007, September 4). Over 6000 churches awaiting registration. The Standard Newspaper, Kenya.

Njiru, A. S. (2001). New Religious Movements in Africa. Nairobi: Paulines Publications Africa.

Ochieng, A. (2018). Kenya $8^{\text {th }}$ on Extreme Poverty List. Business Daily Online. Retrieved from https://www.businessdailyafrica.com.

Ojo, M. A. (2013). Consonance and dissonance in the doctrinal emphasis of prosperity among Nigerian Pentecostal. African Journal of Pentecostal and Charismatic Studies (AJPCS), 1(1), 9-22.

Pew Research Centre. (2010, August 5). Historical Overview of Pentecostalism in Kenya. Retrieved from Pew Research Centre at https://www.pewforum.org/2010/08/05/histori cal-overview-of-pentecostalism-in-kenya/.

Phiri, I., \& Maxwell, J. (2007, July 11). A Cursed Generation of Pastors: Africa's Rapid Embrace of the Rotten Prosperity Pentecostalism Provokes Concern. Christianity Today. https://watchmanafrica.blogspot.com/2009/07/ cursed-generation-of-pastors-africas.html

Shorter, A. \& Njiru, J. (2001). New Religious Movement. Nairobi: Pauline.

Sinitiere, P. L. (2013). Will the evangelical church remove the colour line? Historical reflections on divided by faith. Christian Scholar's Review, 43(1), 41.

Togarasei, L. (2005). Modern Pentecostalism as an urban phenomenon: The case of the Family of God Church in Zimbabwe. Exchange, 34(4), 349-375.

Marshal, R. (1998). Pentecostalism in Southern Nigeria. London: Hurst \& Company. 
East African Journal of Traditions, Culture and Religion, Volume 2, Issue 1, 2020

Article DOI: https://doi.org/10.37284/eajtcr.2.1.141

Wolf, L. (2006). Evangelical \& Pentecostals: Indigenizing a Global Gospel. London: The Open University Press.

Wonsuk, M. (2005). "Doing Theology in the Philippines: A Case of Pentecostal Christianity. Asian Journal of Pentecostal Studies, 215-233. 